\title{
Electron-Transfer Functionality of Synthetic Coiled-Coil Metalloproteins
}

\author{
Michael Y. Ogawa, * Jiufeng Fan, Anna Fedorova, Jing Hong, Olesya A. Kharenko, \\ Anna Y. Kornilova, Robin C. Lasey and Fei Xie
}

\author{
Department of Chemistry and Center for Photochemical Sciences, Bowling Green State University, \\ Bowling Green, $\mathrm{OH} 43403$, USA
}

\begin{abstract}
O campo emergente da engenharia molecular de metaloproteínas visa preparar proteínas artificiais, cujas propriedades podem imitar e talvez até mesmo melhorar várias características encontradas nas metaloenzimas naturais. Este artigo de revisão resume nossos esforços recentes na preparação de metaloproteínas sintéticas, construídas a partir de "coiled-coils" alfa-hélices, e na incorporação de grupos de transferência de elétrons nesses sistemas. Recentemente, concebemos uma cisteína contendo um peptídeo com hélice randômica, o qual forma uma estrutura "coiled-coil" alfa-helicoidal ao se ligar a vários metais. $\mathrm{O}$ aduto de $\mathrm{Cu}^{\mathrm{I}}$ pode atuar como agente fotoindutor de transferência de elétrons para receptores exógenos, e transfere elétrons por colisão na região invertida de Marcus para várias aminas de rutênio, as quais atuam como receptores. Especula-se que este resultado inesperado advenha do posicionamento do cofator de $\mathrm{Cu}^{\mathrm{I}}$ no interior da porção hidrofóbica da proteína, o qual proíbe a aproximação entre o doador e o receptor, diminuindo a velocidade de transferência eletrônica daquelas reações termodinamicamente muito favorecidas, para velocidades inferiores à do limite difusional.
\end{abstract}

The emerging field of metalloprotein design seeks to prepare artificial proteins whose properties can mimic, enhance, and perhaps improve upon many features found in natural metalloenzymes. This review summarizes our recent efforts to prepare synthetic metalloproteins built from $\alpha$-helical coiled-coils and to incorporate electron-transfer functionality within these systems. We have recently designed a cysteine-containing random-coil peptide which forms a $\alpha$-helical coiled-coil upon binding various metals. The $\mathrm{Cu}^{\mathrm{I}}$ adduct can serve as photoinduced electron-transfer agent to exogenous acceptors and undergoes collisional electron-transfer in the inverted Marcus region to various ruthenium ammine acceptors. It is speculated that this unexpected result might be due to the positioning of the $\mathrm{Cu}^{\mathrm{I}}$ cofactor within the hydrophobic core of the protein which prohibits close approach between the donor and acceptor to slow the high driving force reaction rates below the diffusion limit.

Keywords: de novo design, metalloprotein, electron-transfer, $\mathrm{Cu}^{\mathrm{I}}$

\section{Introduction}

Protein-bound metal ions play essential roles in such fundamental biological processes as respiration, metabolism, nitrogen fixation, and signal transduction. In many cases, simple principles of inorganic coordination chemistry can be used to understand the mechanisms of metalloprotein function. However, it is apparent that the protein environment can also play a significant role in fine-tuning the behavior of inorganic cofactors so that they can properly function within the biological milieu. As such, a central focus of the field of bioinorganic chemistry

*e-mail: mogawa@bgsu.edu is to understand the complex relationships that exist between the chemical properties of metal ions and their protein environments.

In addition to studying the activity of naturallyoccurring metalloproteins, the design and preparation of synthetic metalloproteins having tailorable chemical functions is a desirable goal as it holds the promise of developing new types of metalloprotein-based therapeutics, and medical diagnostics in the form of metalbased biosensors and screening agents. ${ }^{1}$ However, such goals now present a formidable challenge to the chemical community as they demand not only the ability to synthesize protein structures capable of binding specific transition metal ions, but also require profound insight 
into the ways that metal ion chemistry can be modified, and perhaps controlled, by protein environments..$^{2-7}$ Such studies are further challenged by the desire to impart specific chemical functions into designed metalloproteins so that they can perform functions which mimic, enhance, or even replace those now performed by native systems.

Two complementary approaches have been taken to synthesize new types of chemically-functional metalloproteins. The "top down" approach refers to the reengineering of native proteins in ways that enable them to perform new chemical tasks which can be significantly different from their inherent biological functionality. $2,5,8,9$ Alternatively, the "bottom-up" strategy for designing functional metalloproteins refers to the rational assembly of discrete peptidic and inorganic building blocks in ways that can create synthetic protein structures whose inorganic components can perform interesting chemical reactions. Here, we will review recent work from our group involving the "bottom-up" design of new hybrid inorganic/biological materials having interesting physical properties. It will be shown how these systems based on the important protein structure motif of $\alpha$-helical coiled-coils provide a new example of how a synthetic protein environment can impart unusual chemical reactivity to its inorganic cofactor.

\section{2. $\alpha$-Helical Coiled-Coils}

For the last several years, our group has been using $\alpha$-helical coiled-coils as scaffolds for constructing miniature metalloproteins. ${ }^{10-19}$ These self-assembled structures are common non-covalent oligomerization sites for proteins which consist of an intertwining of two or more $\alpha$-helices which run in either a parallel or antiparallel direction. ${ }^{20}$ Coiled-coils are stabilized by a specific "knobs into holes" packing arrangement of hydrophobic amino acid side-chains in which a side-chain from one $\alpha$-helix packs into a cavity formed by four side-chains of the complementary helix and form the hydrophobic core of the structure. To best accommodate this packing arrangement, idealized coiled-coils can be constructed from amino acid sequences having a seven-residue (i.e. "heptad") repeat labeled as (abcdefg) in which positions $a$ and $d$ are occupied by hydrophobic amino acids located within the central core of the structure, positions $b, c$, and $f$ are occupied by hydrophilic amino acids that are exposed to the bulk solvent, and positions $e$ and $g$ can be filled by oppositely-charged side-chains to promote the formation of stabilizing inter-chain salt-bridges (Figure 1). These self-assembled structures have been shown to be robust and capable of performing important roles in the formation of interesting new molecular assemblies. ${ }^{21}$ (a)

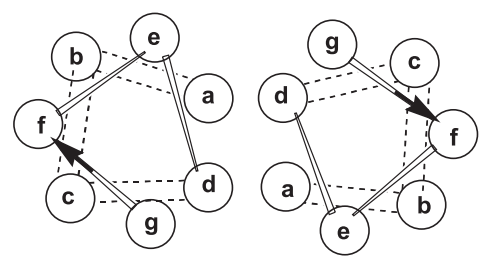

(b)

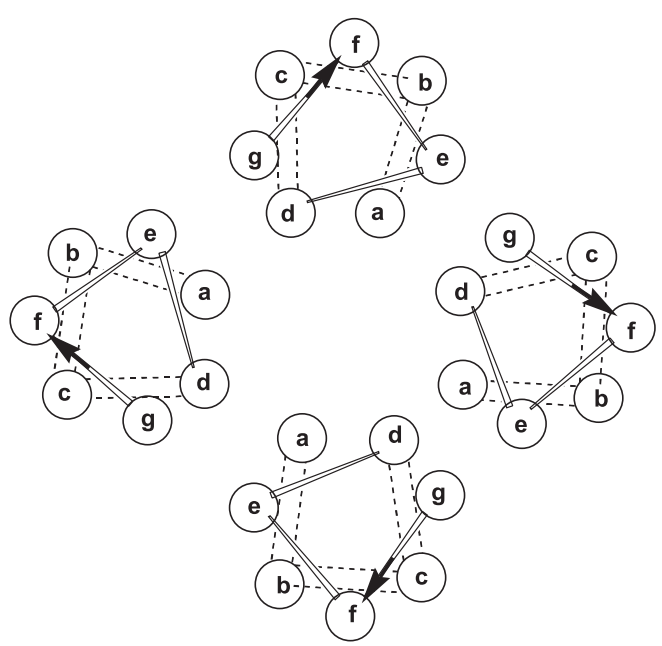

Figure 1. Helical wheel diagrams showing one heptad repeat of (a) a parallel two-stranded coiled-coil and (b) a parallel four-stranded coiledcoil. Note that both structures are stabilized by the "knobs into holes" packing of hydrophobic amino acids side chains occupying the heptad $a$ and $d$ positions of each $\alpha$-helix.

\section{Functionalization of Coiled-Coils with Surface-Exposed Inorganic Redox Centers}

Early work from our group sought to use the structure of a two-stranded $\alpha$-helical coiled-coil as a rigid scaffold upon which inorganic redox centers could be attached in a site-directed manner. Thus, the 30-residue polypeptide called $\mathrm{H} 21(30-\text { mer })^{17}$ was prepared having a sequence based on the (IEALEGK) heptad repeat (single letter amino acid abbreviations: $\mathrm{I}=$ isoleucine, $\mathrm{E}=$ glutamic acid, $\mathrm{A}=$ alanine, $\mathrm{L}=$ leucine, $\mathrm{K}=$ lysine, and $\mathrm{G}=$ glycine). However, in the sequence of H21(30-mer), the most solvent-exposed $f$ position of the third heptad repeat was substituted by the amino acid histidine $(\mathrm{H})$ whose imidazole side-chain is known to bind a variety of different metal complexes. ${ }^{22}$ The subsequent coordination of either a $\left[\mathrm{Ru}\left(\mathrm{NH}_{3}\right)_{5}\right)^{2+}$ or a $\left[\mathrm{Ru}(\text { trpy)(bpy)- }]^{2+}\right.$ center to the histidine residues of the apodimer afforded each of the two ruthenium-modified coiled-coil homodimers. A statistical sample of the electron-transfer active ET heterodimer (Figure 2) was then obtained by annealing an equimolar mixture of the two metallated homodimers 


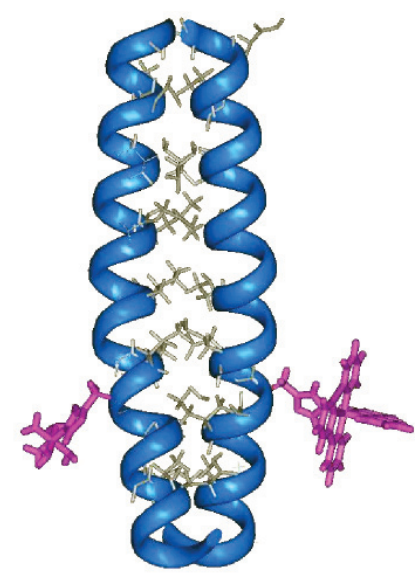

Figure 2. Computer model of the ET heterodimer of ruthenium derivatized H21(30-mer) peptides.

at slightly elevated temperatures. Oxidative pulse radiolysis measurements were used to determine the intramolecular electron-transfer rate constant for the reaction occurring from the $\left[\mathrm{Ru}\left(\mathrm{NH}_{3}\right)_{5} \mathrm{H} 21\right]^{2+}$ donor to the $\left[\mathrm{Ru}(\text { trpy)(bpy)H21'] }]^{3+}\right.$ acceptor of $\mathrm{k}_{\mathrm{ET}}=380 \mathrm{~s}^{-1}$. It is important to note that this reaction occurred over an estimated metal-to-metal distance of $24 \AA$ across a noncovalent peptide-peptide interface. This result shows that the behavior of the model coiled-coil metalloprotein compares favorably with those of both native ${ }^{23}$ and modified $^{22}$ protein systems.

\section{Design of Metal-binding Sites Within the Interior of Coiled-Coils: Metal-induced Protein Folding}

Surface modification of $\alpha$-helical coiled-coils can produce a synthetic metalloprotein having long-range electron-transfer properties which are very similar to those found in natural systems. However, from the perspective of attempting to design synthetic metalloproteins which more closely resemble the structure and properties of natural systems, the ruthenated coiled-coils described above suffer from two major disadvantages. Firstly, whereas the transition metal cofactors of natural proteins are frequently shielded from solvent by being buried within the protein matrix, the histidine metal binding sites of H21(30-mer) were intentionally located at the two solvent-exposed $f$ positions of the coiled-coil in order to promote metal-ion binding. Secondly, the use of preformed ruthenium coordination complexes as redox cofactors necessarily imparts a degree of artificiality to these systems. Thus, we recently undertook the challenge of designing a suitable metal-binding site within the hydrophobic core of a helical coiled-coil to see if such

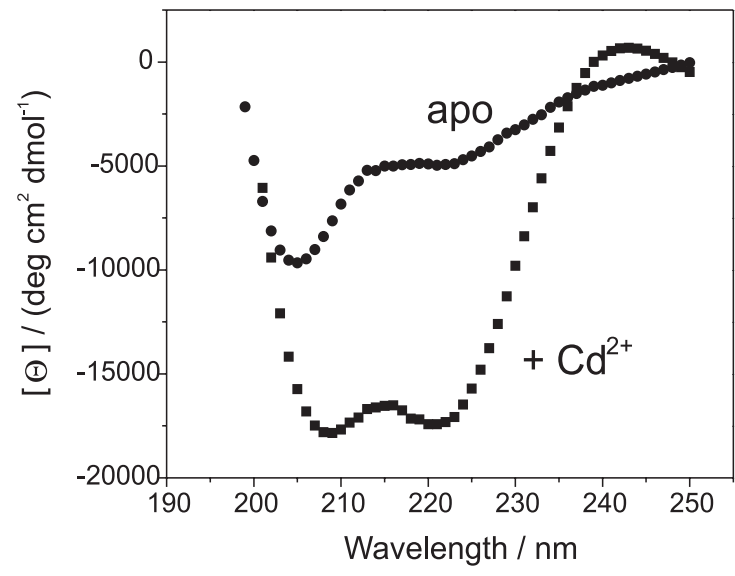

Figure 3. Circular dichroism spectra of C16C19-GGY taken in the absence $(\bullet)$ and presence $(\bullet)$ of $\mathrm{Cd}^{2+}$.

systems can bind redox-active metal ions often found in native proteins.

For simplicity, initial work in this project sought to determine if $\mathrm{Cd}^{2+}$, can bind to the interior of a coiled-coil. ${ }^{13}$ It is noted that whereas $\mathrm{Cd}^{2+}$ is a non-redox active metal ion, strong thiolate to $\mathrm{Cd}^{2+}$ charge-transfer bands are observed which can be used to monitor metal binding. Thus, the 32residue coiled-coil polypeptide called C16C19-GGY was prepared in which cysteine residues were placed at positions 16 and 19 of the sequence which occupy the hydrophobic $a$ and $d$ positions of the third heptad repeat. This design was based on the expectation that the formation of a two-stranded coiled-coil would arrange four cysteine tetrahedral metal binding site similar to that found in rubredoxin, a naturally occurring electron-transfer protein. In an unexpected result, Figure 3 presents circular dichroism (CD) results for the metal-free peptide which is dominated by a negative signal at $195 \mathrm{~nm}$ indicative of a monomeric random coil. Apparently, the presence of the bulky cysteine residues of C16C19-GGY disrupts the peptide's ability to form a two-stranded coiledcoil. However, Figure 3 also shows that the addition of one equivalent of $\mathrm{Cd}^{2+}$ to the peptide produces a dramatic change in the CD signal which now displays two minima of about equal intensities at 208 and $222 \mathrm{~nm}$. These results indicate the presence of a coiled-coil structure and show how metalbinding promotes the formation of an ordered protein structure in this system. Analysis by high performance size exclusion chromatography shows that the Cd-protein exists as a two-stranded coiled-coil, and UV titrations following the growth the charge-transfer band at $238 \mathrm{~nm}$ indicates that a single metal ion was bound to the peptide dimer. The results not only showed that the original design for constructing a coil-coil metalloprotein was successful, but also gave the unexpected result of a dramatic metal-induced protein folding event. ${ }^{13}$ 
The observation that C16C19-GGY undergoes a metalinduced conformational change from a random-coil to a two-stranded coiled-coil prompted further investigation of the metal-binding properties of this peptide. $\mathrm{CD}$ results show that the peptide monomer folds into an $\alpha$-helical coiledcoil when in the presence of such soft metal ions as $\mathrm{Hg}^{\mathrm{II}}$, $\mathrm{Cu}^{\mathrm{I}}, \mathrm{Au}^{\mathrm{I}}$, and $\mathrm{Ag}^{\mathrm{I}}$, but continues to exist as a disordered random coil in the presence of $\mathrm{Fe}^{\mathrm{II}}, \mathrm{Co}^{\mathrm{II}}, \mathrm{Ni}^{\mathrm{II}}, \mathrm{Zn}^{\mathrm{II}}$, and $\mathrm{Pb}^{\mathrm{II}}$. Most interestingly, the oligomerization states of these different metalloproteins range in size from being peptide dimers for the $\mathrm{Cd}^{\mathrm{II}}$ and $\mathrm{Hg}^{\mathrm{II}}$ adducts to peptide hexamers for the $\mathrm{Au}^{\mathrm{I}}$ protein, as determined by HPSEC. The binding of $\mathrm{Cu}^{\mathrm{I}}$ and $\mathrm{Ag}^{\mathrm{I}}$ to $\mathrm{C} 16 \mathrm{C} 19-\mathrm{GGY}$ produces the intermediate case of peptide tetramers, which in the case of the $\mathrm{Cu}^{\mathrm{I}}$ adduct has been verified by analytical ultracentrifugation. However, no obvious trend is observed as binding of the largest ion in the series $\left(\mathrm{Au}^{\mathrm{I}}\right)$ is seen to form the largest peptide oligomer, but the comparably-sized $\mathrm{Ag}^{\mathrm{I}}$ and $\mathrm{Hg}^{\mathrm{II}}$ ions produce peptide tetramers and dimers, respectively. Thus, the binding of different metal ions to the C16C19-GGY peptides produces significant differences in conformational properties of the resulting C16C19-GGY holoproteins. These results indicate that the C16C19-GGY peptide does not have a strong preference for a particular coiled-coil geometry and that the coordination properties of the different metal ions strongly influence the conformation of the resulting metalloprotein.

\section{A Luminescent $\mathrm{Cu}^{\mathrm{I}}$ Coiled-Coil Metallo- protein}

Our studies of the $\mathrm{Cu}^{\mathrm{I}}$ adduct of C16C19-GGY, which exists as a four-stranded coiled-coil, led to the interesting observation of an intense ambient temperature luminescence centered at $600 \mathrm{~nm} .^{12}$ It was found that this luminescence can be quenched by the addition of either ferricyanide, oxygen, or urea to respectively indicate that the emitting species is associated with the reduced $\mathrm{Cu}^{\mathrm{I}}$ state, has significant triplet character, and is quenched upon exposure to bulk solvent. This behavior is reminiscent of earlier studies of small molecule $\mathrm{Cu}^{\mathrm{I}}$ thiolate compounds in which luminescence is observed only for polynuclear metal clusters where metal-metal interactions play an important role in stabilizing the emissive photoexcited-state. ${ }^{24}$ Thus, emission and UV titrations were conducted to determine the metal:peptide stoichiometry and showed that four metal ions bound the peptide tetramer. X-ray absorption spectroscopy further indicated that the four-stranded coiled-coil encapsulated a cyclic $\mathrm{Cu}_{4}^{\mathrm{I}} \mathrm{S}_{4}(\mathrm{~N} / \mathrm{O})_{4}$ cofactor in which each $\mathrm{Cu}^{\mathrm{I}}$ atom is trigonally coordinated to two bridging

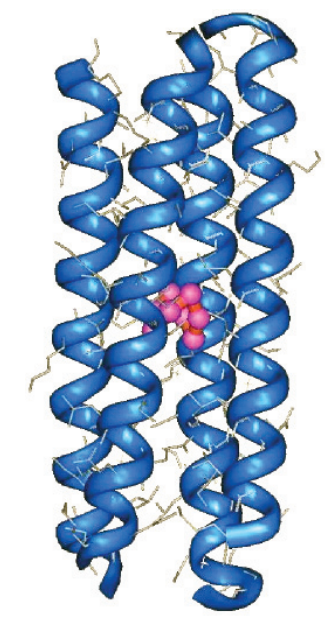

Figure 4. Computer model of the $\mathrm{Cu}(\mathrm{I})$ adduct of C16C19-GGY. The metalloprotein exists as a four-stranded coiled-coil which encapsulates a tetranuclear $\mathrm{Cu}(\mathrm{I})$ thiolate cluster.

cysteine residues and a terminal nitrogen or oxygen ligand (Figure 4).

A combination of emission lifetime and transient absorption studies was used to demonstrate that the highenergy photoexcited state of $\mathrm{Cu}^{\mathrm{I}}$ adduct of C16C19-GGY could be quenched by a variety of ruthenium ammine quenchers by electron-transfer. Linear Stern-Volmer behavior was observed to show that this mechanism involved a purely collisional process. It was further shown (Figure 5) that the emission quenching rate constants decrease with increasing driving force, indicating that the system is in the inverted Marcus region. ${ }^{11}$ The observation of decreasing ET rates with increasing driving force has long been observed in unimolecular, ${ }^{25}$ or otherwise diffusionally-restricted donor/acceptor systems. ${ }^{26,27}$ However, such behavior has rarely been seen in situations in which the donor and acceptor complexes are allowed to freely diffuse in solution where high driving force reactions usually occur at the diffusion limit. ${ }^{28,29}$

Fits of the data obtained for the $\mathrm{Cu}^{\mathrm{I}}$ adduct of $\mathrm{C} 16 \mathrm{C} 19-$ GGY to the Marcus equation (equation 1) yield values of $\lambda \sim 1.7 \mathrm{eV}$ and $H_{D A} \sim 5 \mathrm{~cm}^{-1}$. Assuming $\lambda_{11}=1.20 \mathrm{eV}$ for the ruthenium pentammine acceptors, the Marcus cross relation yields $\lambda_{22}=2.2 \mathrm{eV}$ for the $\mathrm{Cu}^{\mathrm{I}}$ adduct of $\mathrm{C} 16 \mathrm{C} 19$ GGY. Significantly, this large reorganization energy is very similar to that reported for $\left[\mathrm{Cu}(\mathrm{phen})_{2}\right]^{2+/+}(\lambda=2.4 \mathrm{eV})^{30}$ and suggests that the one-electron oxidation of the metalloprotein involves a significant conformational change of

$\mathrm{k}_{\mathrm{ET}}=\sqrt{\frac{4 \pi^{3}}{\mathrm{~h}^{2} \lambda \mathrm{RT}}} \mathrm{H}_{\mathrm{DA}}^{2}(\mathrm{r}) \exp \left\{-\frac{\left(\mathrm{GG}^{0}+\lambda\right)^{2}}{4 \lambda \mathrm{RT}}\right\}$ 
a)

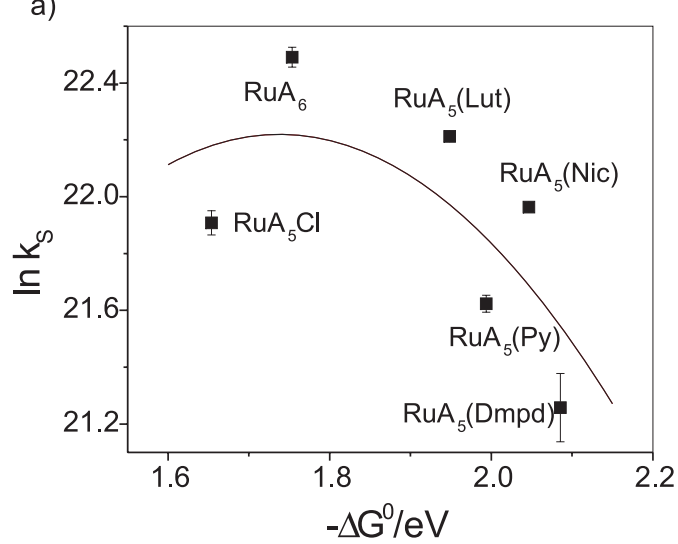

b)

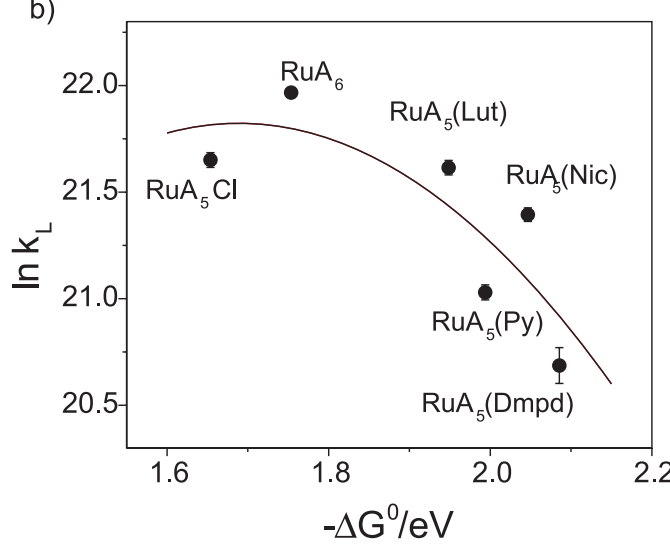

Figure 5. Free energy plot of $\mathrm{k}_{\mathrm{q}}$ values for the short (top) and long (bottom) components to the emission lifetime of the $\mathrm{Cu}(\mathrm{I})$ adduct of $\mathrm{C} 16 \mathrm{C} 19$ GGY in the presence of various ruthenium ammine quenchers. The solid lines are the best fits of the data to equation 1 .

the $\mathrm{Cu}_{4}{ }_{4} \mathrm{~S}_{4}(\mathrm{~N} / \mathrm{O})_{4}$ cluster. The large value of $\lambda$ and small value of $\mathrm{H}_{\mathrm{DA}}$ for $\mathrm{Cu} / \mathrm{C} 16 \mathrm{C} 19-\mathrm{GGY}$ apparently combine to lower the values of $\mathrm{k}_{\mathrm{ET}}$ below the diffusion limit and allow the observation of inverted Marcus behavior. It is speculated that these effects might be due to the positioning of the cofactor within the hydrophobic core of the protein which prohibits close approach between the donor and acceptor. Such results provide an important example of how the appropriate design of synthetic metalloproteins can lead to the development of new chemicals systems possessing unique physical properties.

\section{Conclusions}

It has been shown that $\alpha$-helical coiled-coils can provide a robust scaffold for constructing synthetic metalloproteins having native-like structures. Earlier work from our group showed how surface derivatization of selfassembled coiled-coils can lead to ET behavior similar to those found in native systems. However, more recent work showed how the creation of a chimeric system through the encapsulation of a multinuclear $\mathrm{Cu}^{\mathrm{I}}$ cluster within the interior of a four-helix coiled-coil can lead to novel photophysical behavior that has rarely been seen in either small molecule systems or native metalloproteins alone. It is anticipated that further development of such systems will enable the construction of new hybrid materials which display interesting and useful properties.

\section{Acknowledgments}

This work was supported by National Institutes of Health grant no. GM61171, NSF grant no. CHE-0455441, and ACS-PRF grant No. 34901-AC.

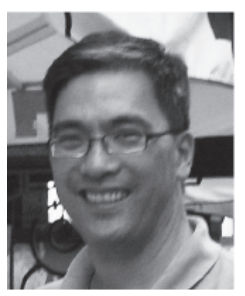

Michael Ogawa is currently Professor and Chair of the Department of Chemistry at Bowling Green State University where is also a Principal Member of the Center for Photochemical Sciences. He received his B.A. from Oberlin College, Ph.D from Northwestern University, and did postdoctoral training at The Rockefeller University and at Rutgers University as a NIH National Research Service Awardee. $H$ is research interests are in the areas of metalloprotein design and electron-transfer reactions.

\section{References}

1. Gilardi, G.; Fantuzzi, A.; Trends Biotechnol. 2001, 19, 468.

2. Barker, P. D.; Curr. Opin. Struct. Biol. 2003, 13, 490.

3. Wittung-Stafshede, P.; Acc. Chem. Res. 2002, 35, 201.

4. Xing, G.; DeRose, V. J.; Curr. Opin. Chem. Biol. 2001, 5, 196.

5. Lu, Y.; Berry, S. M.; Pfister, T. D.; Chem. Rev. 2001, 101, 3047.

6. Kennedy, M. L.; Gibney, B. R.; Curr. Opin. Struct. Biol. 2001, $11,485$.

7. Baltzer, L.; Nilsson, J.; Curr. Opin. Biotechnol. 2001, 12, 355.

8. Bloom, J. D.; Meyer, M. M.; Meinhold, P.; Otey, C. R.; MacMillan, D.; Arnold, F. H.; Curr. Opin. Struct. Biol. 2005, $15,447$.

9. Dwyer, M. A.; Looger, L. L.; Hellinga, H. W.; Science 2004, 304, 1967.

10. Hong, J.; Kharenko, O. A.; Ogawa, M. Y.; Inorg. Chem. 2006, in press.

11. Hong, J.; Kharenko, O. A.; Fan, J.; Xie, F.; Petros, A. K.; Gibney, B. R.; Ogawa, M. Y.; Angew. Chem. Int. Ed. 2006, 37, 6137.

12. Kharenko, O. A.; Kennedy, D. C.; Demeler, B.; Maroney, M. J.; Ogawa, M. Y.; J. Am. Chem. Soc. 2005, 127, 7678.

13. Kharenko, O. A.; Ogawa, M. Y.; J. Inorg. Biochem.2004, 98, 1971. 
14. Fedorova, A.; Chaudhari, A.; Ogawa, M. Y.; J. Am. Chem. Soc. 2003, 125, 357.

15. Fedorova, A.; Ogawa, M. Y.; Bioconjugate Chem. 2002, 13, 150.

16. Kornilova, A. Y.; Wishart, J. F.; Ogawa, M. Y.; Biochemistry 2001, 40, 12186.

17. Kornilova, A. Y.; Wishart, J. F.; Xiao, W. Z.; Lasey, R. C.; Fedorova, A.; Shin, Y. K.; Ogawa, M. Y.; J. Am. Chem. Soc. 2000, 122, 7999.

18. Lasey, R. C.; Banerji, S. S.; Ogawa, M. Y.; Inorg. Chim. Acta 2000, 300-302, 822.

19. Ogawa, M. Y. In Molecular and Supramolecular Photochemistry; Ramamurthy, V.; Schanze, K. S., eds.; Marcel Dekker, Inc.: New York, 1999, vol. 4, pp. 113-150.

20. Cohen, C.; Parry, D. A. D.; Proteins-Structure Function and Genetics 1990, 7, 1.

21. Tsurkan, M. V.; Ogawa, M. Y.; Chem.Commun.2004, 2092.

22. Gray, H. B.; Winkler, J. R.; Q. Rev. Biophys. 2003, 36, 341.
23. Noy, D.; Moser, C. C.; Dutton, P. L.; Biochimica Et Biophysica Acta-Bioenergetics 2006, 1757, 90.

24. Ford, P. C.; Cariati, E.; Bourassa, J.; Chem. Rev. 1999, 99, 3625.

25. Closs, G. L.; Calcaterra, L. T.; Green, N. J.; Penfield, K. W.; Miller, J. R.; J. Phys. Chem. 1986, 90, 3673.

26. McCleskey, T. M.; Winkler, J. R.; Gray, H. B. J. Am. Chem. Soc. 1992, 114, 6935.

27. Gould, I. R.; Farid, S.; Acc. Chem. Res. 1996, 29, 522.

28. Turro, C.; Zaleski, J. M.; Karabatsos, Y. M.; Nocera, D. G.; J. Am. Chem. Soc. 1996, 118, 6060.

29. Fukuzumi, S.; Ohkubo, K.; Imahori, H.; Guldi, D. M.; Chem.Eur. J. 2003, 9, 1585.

30. Gray, H. B.; Malmstrom, B. G.; Williams, R. J. P.; J. Biol. Inorg. Chem. 2000, 5, 551.

Received: July 31, 2006

Published on the web: November 14, 2006 